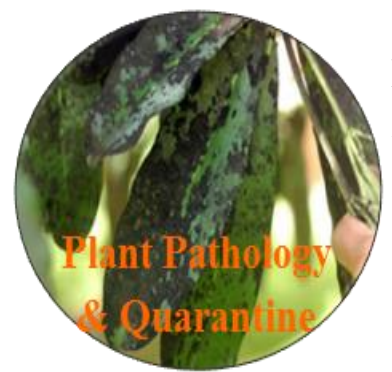

\title{
Article
}

\section{Colletotrichum tropicale causal agent of anthracnose on noni plants (Morinda citrifolia) in Guerrero, Mexico}

\section{Ayvar-Serna $\mathrm{S}^{1}$, Díaz-Nájera $\mathrm{JF}^{1,2 *}$, Vargas-Hernández $\mathbf{M}^{2}$, Plancarte-Galán $\mathbf{P J}^{1}$, Alvarado-Gómez $\mathrm{OG}^{3}$, Tejeda-Reyes MA ${ }^{2}$, Mena-Bahena $\mathrm{A}^{1}$}

\author{
${ }^{1}$ Colegio Superior Agropecuario del Estado de Guerrero, Fitotecnia. Iguala Guerrero, 40000, Estado de Guerrero, \\ México. \\ ${ }^{2}$ Universidad Autónoma Chapingo, Programa de Postgrado en Protección Vegetal. Carretera México-Texcoco km. \\ 38.5, Chapingo, 56230, Estado de México, México. \\ ${ }^{3}$ Universidad Autónoma de Nuevo León, Facultad de Agronomía, Av. Universidad s/n, Cd. Universitaria San Nicolás \\ de los Garza, 66455, Nuevo León, México
}

Ayvar-Serna S, Díaz-Nájera JF, Plancarte-Galán PJ, Vargas-Hernández M, Alvarado-Gómez OG, Tejeda-Reyes MA, Mena-Bahena A 2018 - Colletotrichum tropicale causal agent of anthracnose on noni plants (Morinda citrifolia) in Guerrero, Mexico. Plant Pathology \& Quarantine 8(2), 165169, Doi 10.5943/ppq/8/2/8

\begin{abstract}
During sampling in March 2014 severe anthracnose symptoms were observed, mainly in foliage, on noni plants (Morinda citrifolia) in Cocula, State of Guerrero, Mexico. Fungal monosporic colonies were isolated from leaves with anthracnose symptoms. The morphological characteristics matched those of conidia of Colletotrichum tropicale. DNA analysis was performed on mycelium of the fungus by PCR amplification of ITS sequences. The identification and pathogenicity of isolates was confirmed by inoculation of the pathogen onto healthy plants free from disease. Control plants remained healthy, while those inoculated with the pathogen developed lesions and symptoms of rot anthracnose eight days after inoculation. The morphological, molecular characteristics and pathogenicity tests of the isolates confirmed that $C$. tropicale is the causal agent of anthracnose in M. citrifolia.
\end{abstract}

Key words - anthracnose - diagnosis - Morinda citrifolia - PCR

\section{Introduction}

Noni is the Hawaiian name given to the fruit of Morinda citrifolia L. (Rubiaceae). This species, which originated from Southeast Asia to the Australian region, is grown in Polynesia, India, Caribbean, Mexico, Central and South America. The Polynesians have used this plant for over 2000 years as a source of food and for medicinal purposes (Ulloa et al. 2012). There is evidence that noni has been used in traditional medicine in which the fruit helps to prevent and cure various diseases; these benefits include stimulation of the immune system, thus fighting against bacteria, viruses, parasites and fungal infections, preventing the formation of tumors including some malignant types (McClatchey 2002, Ulloa et al. 2012). Two clinical studies reported the relief of arthritis and diabetes associated with noni consumption; this is due to the beneficial effect that exists in certain compounds such as scopoletin, alkaloids and sterols as well as its antioxidant effects (Swetal \& Krishanamurthy 2013). In Mexico, the leading producer of noni is the State of 
Nayarit, with 36.55 hectares of cultivated area and total production of 220.12 tons (SIAP 2018). The State of Guerrero has rapidly increased its demands for noni, and so have established new commercial plantations, principally in "La Costa Grande", although there are no updated statistics to prove the cultivated and production areas, or yield. In these plantations there is evidence that anthracnose exists, affecting branches, leaves, flowers and fruits; but in Mexico there is no reported knowledge on research of the phytosanitary status of noni plants, but in other parts of the world there are reports on the occurrence of Colletotrichum spp. in noni (McKenzie 1989, McKenzie \& Jackson 1990a, b, Kumar et al. 2012, Hubballi et al. 2012). However, previous reports did not use molecular techniques to determine the species of Colletotrichum involved. For this reason, there was urgent interest in investigating the etiology of this disease.

\section{Materials \& Methods}

\section{Collection of samples, isolation, pathogenicity test, morphological and molecular identification}

During March 2014, noni leaves with different symptoms of anthracnose were collected from an established plot in the experimental field area of the Agricultural College (CSAEGro) in Cocula, State of Guerrero, Mexico at coordinates $18^{\circ} 19^{\prime} \mathrm{N}, 9^{\circ} 39^{\prime} \mathrm{W}$ (Díaz et al. 2018). Using a systematic $\mathrm{W}$ transect sampling method, 20 leaves were collected. The symptoms were lesions on leaves, represented by light brown to dark and sometimes irregular circular spots. On the leaves with symptoms, a $1 \mathrm{~cm}^{2}$ section was made in the transition zone between healthy and necrotic tissue. The tissue fragments were sterilized with sodium hypochlorite $(1.5 \% \mathrm{NaOCl})$ for 2 minutes, rinsed three times with sterile distilled water and allowed to surface dry on paper towels for 2 minutes. One hundred tissue samples were processed and five pieces were placed in each Petri dish containing potato dextrose agar (PDA) culture medium. The dishes were incubated at $24{ }^{\circ} \mathrm{C}$ in alternating light/dark. Actively growing fungal colonies were then transferred to new PDA medium in order to obtain monoconidial cultures (Crous et al. 2009). The isolated fungi were identified according to their conidia. Temporary slides of isolated pure fungal cultures were prepared in glycerol. The slides were observed using a light microscope $(400 \times)$, and size and shape of conidia noted. Identification was carried out by comparing the morphological structures and following fungal keys of Barnett \& Hunter (1998), Watanabe (2002), Rojas et al. (2010).

A conidial suspension of the commonly isolated fungus was prepared containing $8 \times 10^{5}$ conidia per $\mathrm{mL}^{-1}$. This was sprayed at the rate of $2.5 \mathrm{~mL}$ on to healthy, 70-days-old, M. citrifolia plants, and on to healthy fruits, of about $100 \mathrm{~g}$, until dripping point. A wetting agent, Tween $20^{\circledR}$, was added at the rate of $2 \mathrm{~mL}$ per liter of sterile distilled water. The control consisted of three plants and five fruits that received only sterile distilled water. All plants were placed in a humidity chamber for seven days at $22 \pm 2{ }^{\circ} \mathrm{C}$ and $100 \%$ relative humidity. Once the inoculated plants showed the same symptoms as those of the first tissues collected, re-isolation was carried out using the method described by Núñez et al. (2013).

DNA extraction was performed with 50 to $100 \mathrm{mg}$ of pure isolate mycelium grown in PDA using the QIAGEN DNeasy Mini Kit according to the manufacturer's instructions (QIAGEN ${ }^{\circledR}$, Hilden, Germany). The procedure was repeated four times for each isolate. Universal PCR reactions were performed using primers ITS-1fu 5'-tccgtaggtgaacctgcgg-3' and ITS-4 5'tcctccgcttattgatatgc-3' (White et al. 1990), which amplify two internal transcribed spacers (ITS) and 5.8S ribosomal RNA gene, generating a product between 566 and 570 base pairs (bp). The reaction mixture used for PCR amplification was prepared containing: $1 \mathrm{X}$ Taq DNA polymerase buffer, $2 \mathrm{nM} \mathrm{MgCl} 2,200 \mathrm{mM}$ dNTP, $20 \mathrm{pMol}$ of each oligonucleotide primer and 1 unit of Taq polymerase enzyme (Promega, WI, USA) in a final volume of $25 \mu \mathrm{L}$. The thermal program used was at a temperature of $94{ }^{\circ} \mathrm{C}$ for 2 minutes followed by 35 cycles at $94{ }^{\circ} \mathrm{C}, 55{ }^{\circ} \mathrm{C}$ and $72{ }^{\circ} \mathrm{C}$ for 30,30 and 60 seconds, respectively, and a final extension of 5 minutes at $72{ }^{\circ} \mathrm{C}$. PCR reaction products were electrophoresed on $1.5 \%$ agarose gel, and the bands viewed using a UVP ultraviolet 
light transilluminator. The PCR-amplified fragments were sequenced directly and then compared to similar sequences available in GenBank, National Center for Biotechnology Information (NCBI).

\section{Results}

During field sampling it was observed that the damage to $M$. citrifolia leaves was very severe when high humidity and precipitation, interspersed with periods of drought occurred. Fungal colonies developed on PDA, and were identified as Colletotrichum tropicale. This fungus produced unicellular hyaline conidia, subterete, with rounded ends and measuring 13-17.5 × 4.7-5.3 $\mu \mathrm{m}$ (Fig. 1A, B). On PDA abundant conidia were formed in concentric rings. The slimy conidial masses in the initial stages was brown-orange and finally brown (Fig. 1C, D, E).

Eight days after inoculation with $C$. tropicale conidia suspension all plants showed symptoms on leaves ranging from pale lesions to dark brown circular and irregular spots (Fig. 2, left), while the control plants remained free of disease (Fig. 2, right), in the inoculated fruits the symptoms of anthracnose were manifested, the control fruits remained healthy. Colletotrichum tropicale was reisolated from symptomatic plants and fruits.

The obtained sequences (550 and $551 \mathrm{bp}$ ) showed 100\% similarity to the ITS region, and their alignment coincided with sequences reported in GenBank for $C$. tropicale. The accessions KX364718.1, KX364719.1, CSAEGro-PAYDI 0.1 and CSAEGro-PAYDI 0.2 were deposited in GenBank.

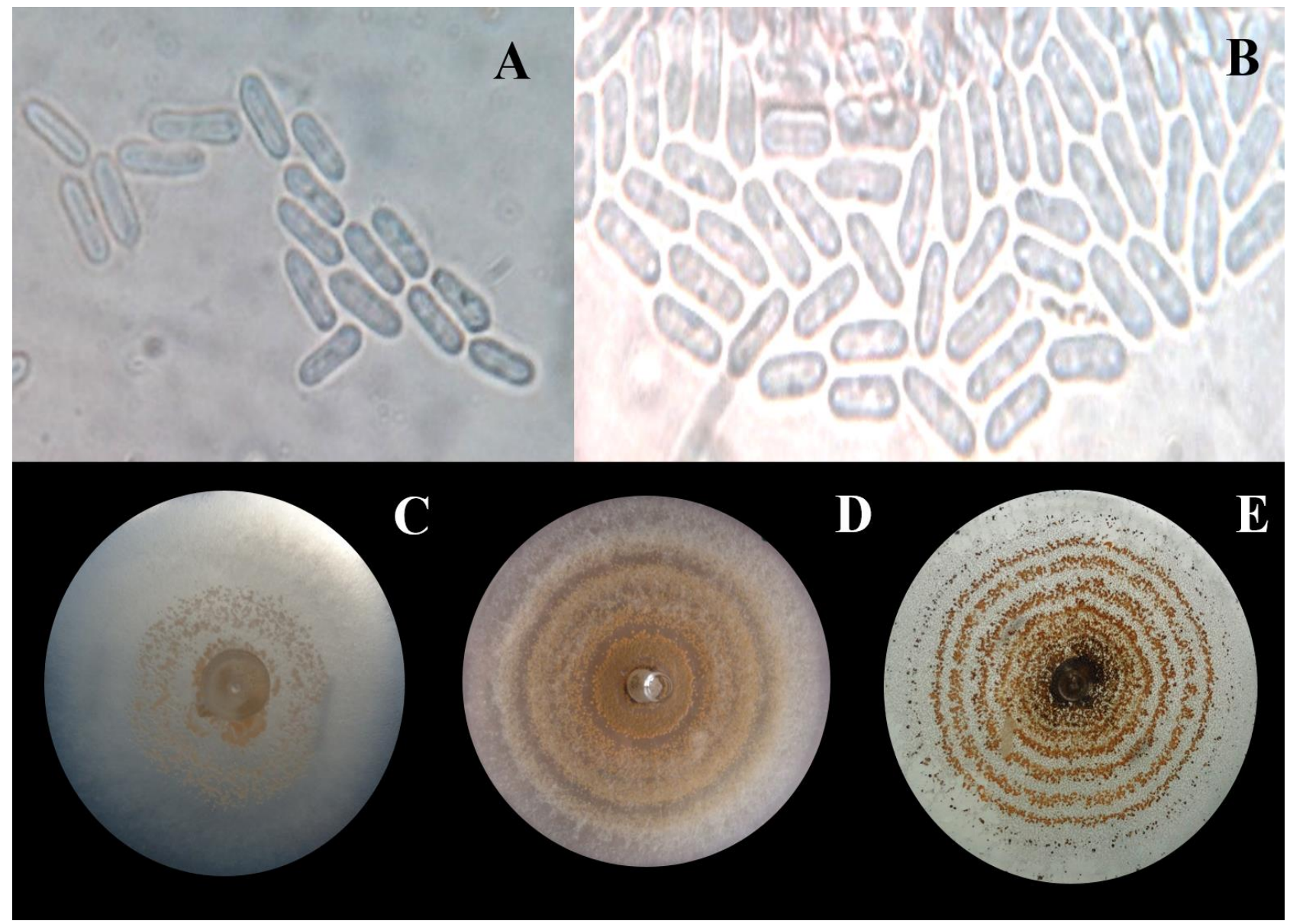

Fig. 1 -Colletotrichum tropicale. A, B Conidia. C, D, E Cultural characteristics on PDA.

\section{Discussion}

The morphological features of the isolated fungus corresponded to descriptions by Barnett \& Hunter (1998), Watanabe (2002) for the genus Colletotrichum, and to Rojas et al. (2010) for $C$. tropicale. The symptoms were similar to those reported by Hubballi et al. (2012), Kumar et al. 
(2012) who inoculated M. citrifolia with C. gloeosporioides and Colletotrichum spp. in fruits, typical necrotic anthracnose lesions was presented. Recently, several authors have pointed out the incidence of $C$. tropicale in various crops. On comparing the sequences obtained in this investigation with sequences available in GenBank, we found similarities of $99 \%$ and $100 \%$, with previously reported sequences of C. tropicale KC512125.1 obtained from Anona muricata in Colombia Álvarez et al. (2014), García \& Manzano (2017) reported the anthracnose incidence in pre-harvest in fruits of Annona cherimola caused by $C$. tropicale in Cuba (Accession Nos. LT853592, LT853593 and LT853594). Araújo et al. (2018) reported C. tropicale (MF289371.1) causing anthracnose on fruits of carnauba palm in Brazil. Weir et al. (2012) report that within the complex of $C$. gloeosporioides, 22 subspecies are grouped, which include among others $C$. tropicale, according to the authors the subspecies are defined genetically on the basis of phylogeny, in addition brief morphological descriptions are provided for the species where there is no modern description available.

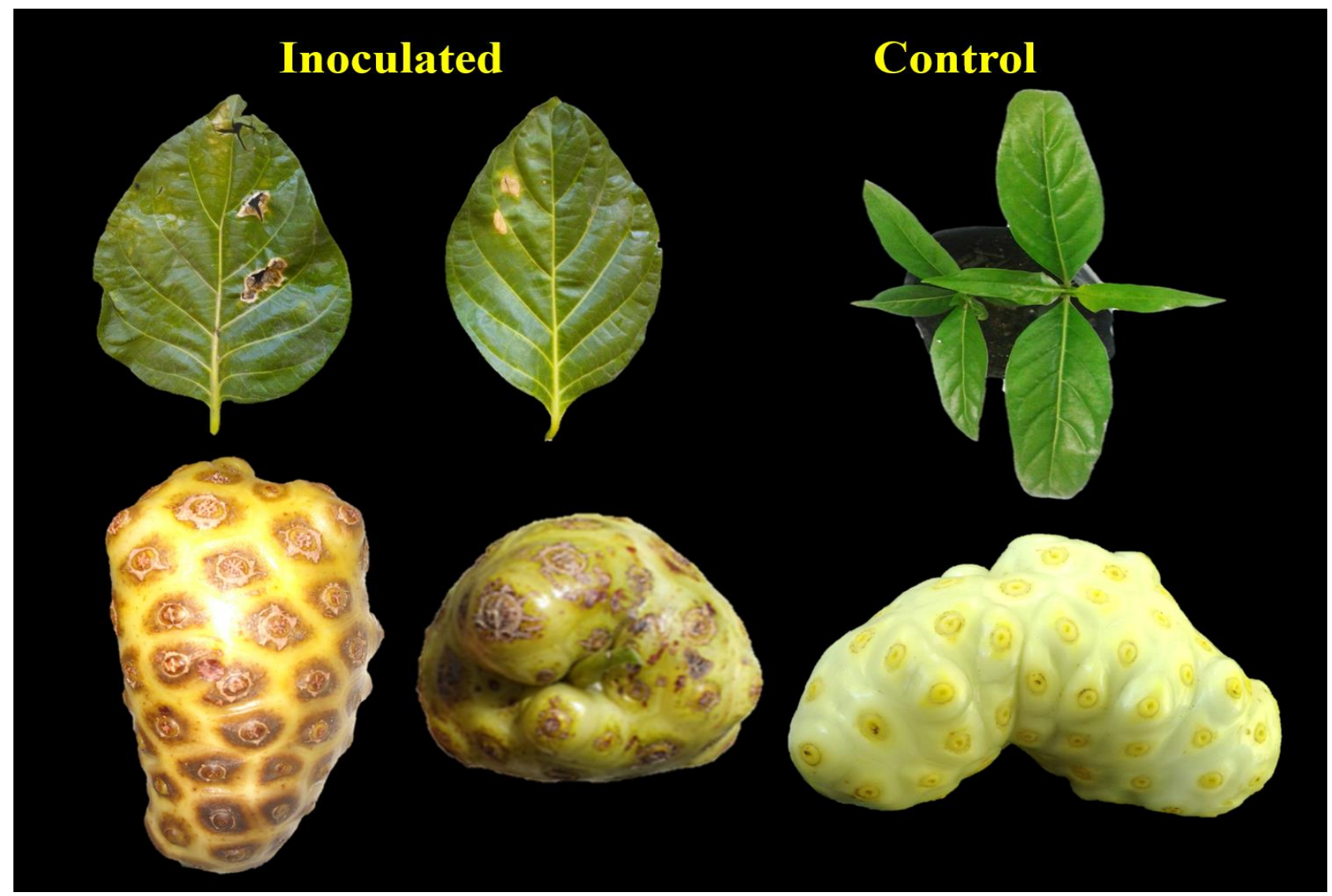

Fig. 2 - Pathogenicity test with Colletotrichum tropicale on Morinda citrifolia. Control leaves and fruit (right), inoculated leaves and fruit (left).

\section{References}

Álvarez E, Gañán L, Rojas TA, Mejía JF et al. 2014 - Diversity and pathogenicity of Colletotrichum species isolated from soursop in Colombia. European Journal of Plant Pathology 139(2), 325-338. doi.org/10.1007/s10658-014-0388-7.

Araújo MBM, Lima CS, Rabelo-Filho FAC, Ootani MA et al. 2018 - First report of Colletotrichum theobromicola and C. tropicale causing anthracnose on fruits of Carnauba palm in Brazil. Plant Disease 102(1), 244. doi.org/10.1094/PDIS-06-17-0860-PDN

Barnett H, Hunter B. 1998 - Illustrated Genera of Imperfect Fungi, 4th ed. APS Press, St. Paul, Minnesota. 217 p. 
Crous PW, Verkleij GJM, Groenewald JZ, Samson RA. 2009 - Fungal Biodiversity. CBS Laboratory Manual Series 1. Centraalbureau voor Schimmelcultures, Utrecht.

Díaz-Nájera JF, Ayvar-Serna S, Vargas-Hernández M, Sahagún-Castellanos J et al. 2018 - First report of squash leaf curl virus detected in Proboscidea louisianica in Mexico. Plant Pathology \& Quarantine 8(2), 140-143. Doi 10.5943/ppq/8/2/5.

García L, Manzano AM. 2017 - First report of anthracnose on cherimoya caused by Colletotrichum tropicale in Cuba. Journal of Plant Pathology 99(3), 799-818.

Hubballi M, Nakkeeran S, Raguchander T. 2012 - First report of anthracnose on noni caused by Colletotrichum gloeosporioides in India. Archives of Phytopathology and Plant Protection 45(3), 276-279.

Kumar K, Singh DR, Amaresan N, Madhur K. 2012 - Isolation and pathogenicity of Colletotrichum spp. causing anthracnose of Indian mulberry (Morinda citrifolia) in tropical islands of Andaman and Nicobar, India. Phytoparasitica 40, 485-491.

McClatchey WC. 2002 - From Polynesian healers to health food stores: changing perspectives of Morinda citrifolia (Rubiaceae). Integrated Cancer Therapies 4, 110-120.

McKenzie EHC. 1989 - The fungi, bacteria, and pathogenic algae of Vanuatu. Forum Secretariat. Suva, Fiji. 91 p.

McKenzie EHC, Jackson GVH. 1990a - The fungi, bacteria and pathogenic algae of the Republic of Palau. SPC Technical Paper 198. 41 p.

McKenzie EHC, Jackson GVH. 1990b - The fungi, bacteria and pathogenic algae of the Federated States of Micronesia. SPC Technical Paper 199. 67 p.

Núñez-Rios T, Leyva-Mir SG, Rodríguez-Pérez JE, Mariscal-Amaro LA. 2013 - Etiología y control de la necrosis de flores y pudrición de frutos de pepino en Morelos, México. Revista Chapingo Serie Horticultura 19(2), 255-266.

Rojas EI, Rehner SA, Samuels GJ, Van-Bael SA et al. 2010 - Colletotrichum gloeosporioides s. 1. associated with Theobroma cacao and other plants in Panama: multilocus phylogenies distinguish host-associated pathogens from asymptomatic endophytes. Mycologia 102(6), 1318-1338.

SIAP. 2018 - Secretaria de Agricultura, Ganadería, Desarrollo Rural, Pesca y Alimentación (SAGARPA) Servicio de Información Agroalimentaria y Pesquera (SIAP). Retrieved July 2018, from: http:www.siap.gob.mx.

Swetal P, Krishanamurthy R. 2013 - Review on noni (Morinda citrifolia L.) - a herbal remedy for better health. Global Journal of Research on Medicinal Plants \& Indigenous Medicine 2(5), 337-347.

Ulloa JA, Rosas UP, Ramírez RJC, Ulloa RBE. 2012 - The noni: potential properties, uses and applications. Revista Fuente 10, 44-49.

Watanabe T. 2002 - Pictorial Atlas of Soil and Seed Fungi. Morphologies of Cultured Fungi and Key to Species, 2nd ed. CRC Press, New York Washington, DC. 500 p.

Weir B, Damm U, Johnston PR. 2012 - The Colletotrichum gloeosporioides species complex. Studies in Mycology 73, 115-180.

White TJ, Burns T, Lee S, Taylor J. 1990 - Amplification and direct sequencing of fungal ribosomal RNA genes for phylogenetics. In: Innis MA, Gelfand DH, Sninsky JJ, White TJ. (eds). PCR Protocols: A Guide to Methods and Applications, pp. 315-322. Academic Press, San Diego, CA, USA. 